\title{
Correction to: Patella-patellar tendon angle and lateral patella-tilt angle decrease patients with chondromalacia patella
}

\author{
Lale Damgacı $^{1}$ [D $\cdot$ Hamza Özer ${ }^{2} \cdot$ Semra Duran $^{1}$
}

Published online: 12 June 2020

(c) European Society of Sports Traumatology, Knee Surgery, Arthroscopy (ESSKA) 2020

\section{Correction to:}

\section{Knee Surgery, Sports Traumatology, Arthroscopy} https://doi.org/10.1007/s00167-020-06065-7

Authors would like to correct the error in article title which should be "lateral patella-tilt angle" instead of tibial angle. The corrected version updated here.

The original article has been corrected.

Publisher's Note Springer Nature remains neutral with regard to jurisdictional claims in published maps and institutional affiliations.

The original article can be found online at https://doi.org/10.1007/ s00167-020-06065-7.

Lale Damgac1

ldamgaci@ hotmail.com

Hamza Özer

hozermd@gmail.com

Semra Duran

semraduran91@gmail.com

1 Ankara City Hospital, Üniversiteler mh. Bilkent cd. No: 1, 06800 Çankaya/Ankara, Turkey

2 Zeynep Kamil Women's and Children's Disease Training and Research Hospital, Zeynep Kamil mh. Dr. Burhanettin Üstünel Sokağı No: 10, 34668 Üsküdar/İstanbul, Turkey 